\title{
Assessment of soil organic carbon fractions and carbon management index under different land use types in Olesharo Catchment, Narok County, Kenya
}

\author{
Bernice M. Sainepo ${ }^{{ }^{*}}\left(\mathbb{0}\right.$, Charles K. Gachene ${ }^{1,2}$ and Anne Karuma ${ }^{1}$
}

\begin{abstract}
Background: The changes in land use and land cover have a strong effect on the total soil organic carbon, its fractions and its overall soil health. This study carried out in Olesharo Catchment, Kenya, was to quantify the differences in total organic carbon (TOC), particulate organic carbon (POC), mineral organic carbon (MOC) and carbon management index (CMI) among four land use types: grasslands, shrublands, agricultural lands and barelands. It was also purported to evaluate the use of $\mathrm{CMI}$ as an indicator for soil degradation or improvement in response to land use and land cover changes.

Results: The results of the study show that the mean values of TOC, POC and MOC are significantly different between land use types. Thus, shrublands have significantly higher TOC $\left(22.26 \mathrm{~g} \mathrm{~kg}^{-1}\right)$ than grasslands $\left(10.29 \mathrm{~g} \mathrm{~kg}^{-1}\right)$ and bare lands $\left(7.56 \mathrm{~g} \mathrm{~kg}^{-1}\right)$. They also have significantly higher POC $\left(7.79 \mathrm{~g} \mathrm{~kg}^{-1}\right)$ and MOC $\left(10.04 \mathrm{~g} \mathrm{~kg}^{-1}\right)$ than all the other land use types. The agricultural lands have higher CMI than grasslands (53\% vs $41 \%$ relative to shrublands) suggesting that grasslands face serious degradation through overgrazing.

Conclusions: This study shows that different land use types have an influence on soil organic carbon pools, and consequently on the CMI, the CMI could be used as an indicator for soil degradation or improvement in response to land use and land cover changes.
\end{abstract}

\section{Background}

Increasing anthropogenic disturbances especially, on land use/cover change (LULCC), is the major cause of soil quality deterioration in the world [1]. Soil organic carbon (SOC) has recently gained prominence in assessment of soil quality since it compoundly affects chemical, physical and biological aspects of the soil. Though described by some as the least most understood component of the soil because of its dynamism, [2] SOC has been linked to its potential role in carbon sequestration through proper management of land use and cover types [3]. Land use and cover types influence $C$ fluxes in an

\footnotetext{
*Correspondence: bernicesainepo@gmail.com

1 Department of Land Resource Management and Agricultura Technology, University of Nairobi, P.O Box 29053, Nairobi 00625, Kenya Full list of author information is available at the end of the article
}

ecosystem; through litter quality, deposition and turnover rate. Although SOC is an indicator of soil quality, conceptualization of soil fractions can be used to detect even slight changes in management and regulate degradation $[4,5]$.

Soil organic matter can be divided into several fractions depending on their densities. Labile fraction (LF) is the most prominent, partly due to its high turnover rate plus it is easily affected by management systems as well as erosion [6-8]. Labile fraction has been described in various ways by soil scientists, including particulate organic carbon (POC) $(53-2000 \mu \mathrm{m})$, light fraction organic carbon (LFOC) (density of $<2.0 \mathrm{~g} \mathrm{~cm}^{-2}$ ), readily oxidized carbon (ROC) (easily oxidized by potassium permanganate), soil microbial biomass carbon (SMBC) and dissolved organic carbon (DOC), etc. [9-11]. 
The labile fraction (LF) consists of the mineral-free SOM composed of partly decomposed plant and animal residues which turn over rapidly and have a specific density that is comparatively lower than that of soil minerals [12]. Agricultural soils have been identified as having the lowest LF $[13,14]$ due to high disturbances by tillage practices and harvesting of crop residues. In native land cover types (forests, grasslands, shrublands) however, high LF has been recorded due to high litter input and controlled soil temperature. Grazing has been seen to increase lability of carbon through activation of microbial activity by enzymes found in the saliva and dung from herbivory especially in warm temperatures [1518]. Moreover the removal of biomass promote plant regrowth hence expedite nutrient cycling within the rhizosphere. With increase in grazing intensity, LF has been seen to significantly reduce [11], attributable to low litter deposition, high mineralization due to exposure to surface temperature and intensive erosion.

Stable fraction (SF) accounts for $90 \%$ of the total organic carbon (TOC) in terms of particle size distribution [6]. Most studies show that SF due to its recalcitrant nature is not easily affected by land use or management practices [19], while others show that this fraction is more affected than the labile portion [20,21]. The SF arguable is said to be resistant to management systems due protection from external factors by sorption on fine particles. Its inaccessibility to decomposing microbes is due to dominance of clay particles that strongly adsorb the carbon protecting it from enzymatic action leading to the humification process [22].

There are different techniques that partition the fractions into functional pool. In this study the physical fractionation based on particle size of organic matter was used as opposed to the conventional $\mathrm{KMnO}_{4}$. Researches against the latter address the limitations that the concentrations are often too strong therefore detection of changes in the lability often goes unnoticed ([23]. Moreover, other studies show that the reaction times are not standard as they differ with the soil sample moisture and the decomposition of $\mathrm{KMnO}_{4}$ when exposed to light [9]. Whereas in support of physical fractionation, the process is able to disintegrate the POC particles to effectively detect the LF as opposed to the chemical method which is a surface attack and may provide underestimate values of the fractions [24]. Therefore the use of sieves to separate SOC fractions was employed following the study by [25] where labile fractions are to be found between sieves of sizes $53-250 \mu$ and the stable ones $<53 \mu$.

Although total soil carbon varies with soil management, it is not as sensitive as the LF in short durations [26]. Therefore, calculation of the lability of SOC within each land cover type can be used as an early indicator for soil degradation or improvement in response to different management practices. In order to use more sensitive indicators, the development of carbon management index (CMI) has been used in different land uses to evaluate the capacity of a land use to promote soil quality [4, 27]. It involves the calculation of lability which is a ratio of the labile carbon to the non-labile carbon. Studies that use CMI as an assessment tool are rare, therefore the objective of this study is to investigate the SOC dynamics in each LULUCs types of the Olesharo Catchment area, Narok, Kenya and develop a CMI.

\section{Methods}

\section{Description of study site}

The study was carried out in Suswa Location (Fig. 1), Narok County located in the Southwest of Kenya. The County lies between longitudes $34^{\circ} 45^{\prime} \mathrm{E}$ and $36^{\circ} 00^{\prime} \mathrm{E}$ and latitudes $0^{\circ} 45^{\prime} \mathrm{S}$ and $2^{\circ} 00^{\prime} \mathrm{S}$. The topography ranges from a plateau with altitudes ranging from 1000 to $2350 \mathrm{~m}$ a.s.l. at the southern parts to mountainous landscape (3098 m a.s.l) at the top of the Mau escarpment in the North [28-30].

The catchment is located within agro-climatical zones (ACZ) IV which is semi-humid to semi-arid [31]. The area experiences a bi-modal pattern of rainfall with long rains expected from mid-March to June and short rains from September to November. The local fluctuations in topography influences the rainfall distribution patterns, with the highlands receiving as high as $2000 \mathrm{~mm}_{\text {year }}{ }^{-1}$ while the lower and drier areas receiving less than $500 \mathrm{~mm}$ year $^{-1}$ [32].

The Suswa area has steep gradients and volcanicash soils, mainly Andosols, which are prone to erosion. There are visible patches of bare land that have developed due to overgrazing. The Suswa hill is dominated by an intricate network of deep gullies reaching to $4 \mathrm{~km}$ in length, $25 \mathrm{~m}$ deep and widths of over $30 \mathrm{~m}$ [33]. Geomorphologically, there are pronounced cattle tracks and evidence of intense runoff and flash floods during the rains [34]. The area is dominated by scattered acacia tree species and Thaconathusz camphoratus which is an indication of dry weather conditions and depressed rainfall amounts [35].

\section{Land use}

Narok County has diverse land use types spanning the agroecological zones that occur in the area. The catchment is found within the Narok County which is predominantly a semi-arid climate. Olesharo is found within the lower elevations of the County where there is a prominent transition from pastoralism to agropastrolism. The area is dominated by shrubland and grassland with patches of agricultural land and bareland (Table 1). Croplands have grown in the recent decade as a way to 


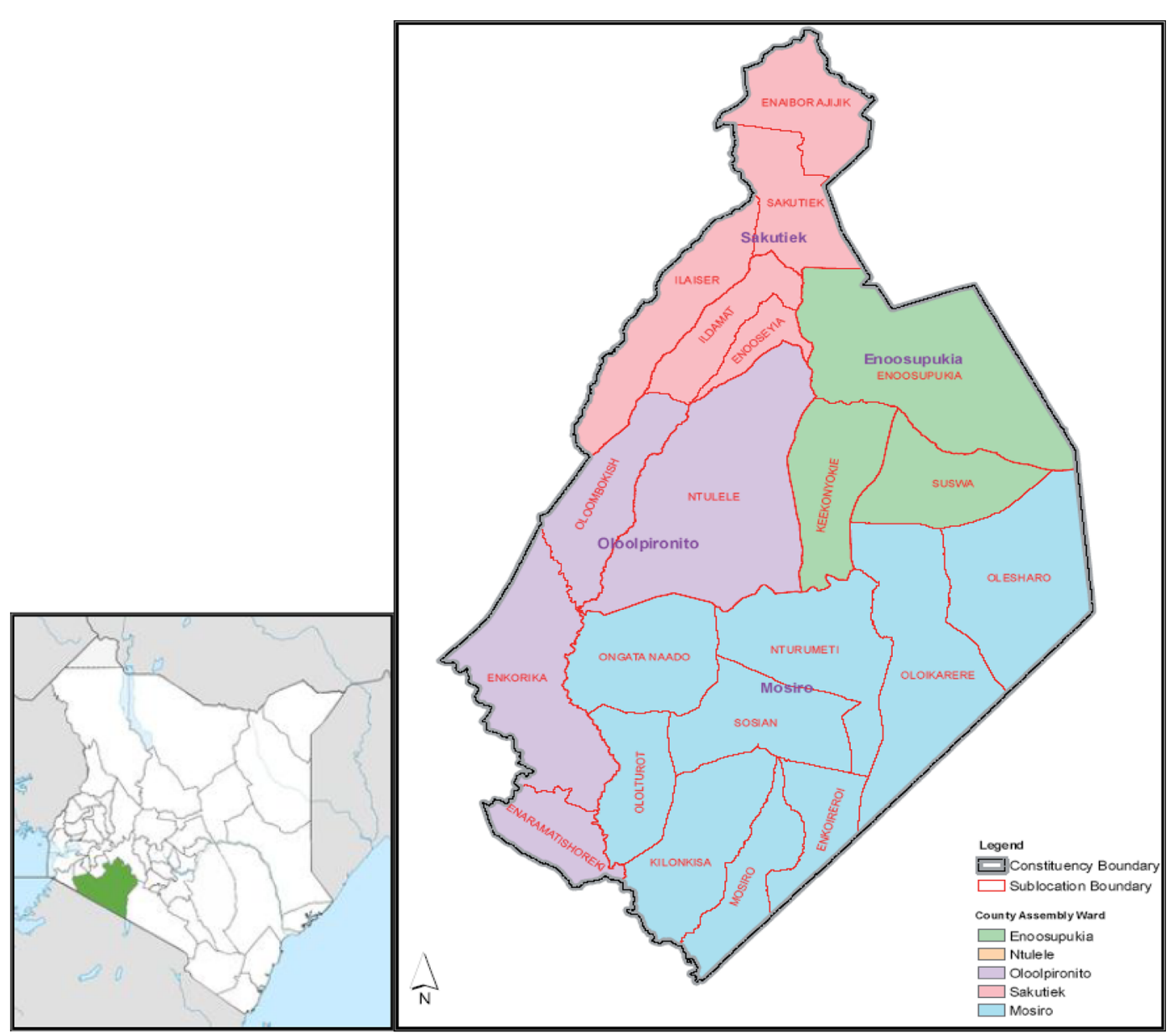

Fig. 1 The study area in Narok County (Source: Narok District Environment Action Plan 2009-2013)

Table 1 Land use/cover change in Mount Suswa Catchment (1985-2011)

\begin{tabular}{|c|c|c|c|c|c|c|c|c|c|}
\hline Land use/cover & 1985 area $\left(\mathrm{km}^{2}\right)$ & $\%$ & 2000 area $\left(\mathrm{km}^{2}\right)$ & $\%$ & 2011 area $\left(\mathrm{km}^{2}\right)$ & $\%$ & $\begin{array}{l}\text { \%change } \\
1985-2000\end{array}$ & $\begin{array}{l}\text { \%change } \\
2000-2011\end{array}$ & $\begin{array}{l}\text { \%change } \\
1985-2011\end{array}$ \\
\hline Built up area & 0.77 & 0.19 & 0.91 & 0.24 & 1.30 & 0.32 & +18.18 & +42.86 & +68.83 \\
\hline Agricultural land & 1.00 & 0.02 & 15.33 & 3.81 & 23.16 & 5.76 & +1433 & +51.08 & +2216 \\
\hline Shrubland & 231.1 & 57.4 & 170.6 & 42.4 & 237.8 & 59.1 & 26.18 & +39.39 & +2.90 \\
\hline Bareland & 1.21 & 0.30 & 12.44 & 3.11 & 2.46 & 0.61 & +928.1 & +405.69 & +103.3 \\
\hline Grassland & 166.71 & 41.45 & 188.92 & 46.97 & 137.68 & 34.2 & +13.32 & -27.12 & -17.41 \\
\hline
\end{tabular}

diversify production due to the changing climate. Farming is a monocrop of maize (Kenyan staple crop), and/or an intercrop of maize and beans. Sheep, goats and beef/ dairy cattle is the predominant livelihood activity, with bee keeping in selected households $[29,36]$. The area is also populated with wildlife which is exploited for tourism and ecotourism [37]. The community land has now been partitioned therefore wildlife and livestock mobility is curtailed; this in turn has had severe detrimental effects on soil erosion.

\section{Suswa soils}

The Suswa area has humic andosols, well drained, relatively deep, dark brown, friable and smeary, sandy clay to clay, with acidic humic topsoil $[29,38]$. These soils have sand to clay ratio of $2: 1$ on average for the horizons 
studied [39]. The high silt/clay ratio, low organic matter and high bulk density which may be due to compaction as a result of continuous grazing in the area, among other factors, have made the soils more vulnerable to erosion. The soils are stratified with hard pans underlain by soft clayish strata that are readily eroded [36].

\section{Sampling design and soil sampling}

Sites were selected to minimize soil variability. Six plots per each LUT of $30 \times 30 \mathrm{~m}$ were randomly selected were laid on the different land use types that were identified using the Landsat maps): agriculture, bareland, grassland and shrubland. In each plot, an auger was used to collect disturbed soil samples from the centre and four corners of the plot at $0-15$ and $15-30 \mathrm{~cm}$ depth. The samples taken from the corresponding depths were thoroughly mixed and bulked into one composite sample of about $500 \mathrm{~g}$. At the centre, soil core rings ( $5 \mathrm{~cm}$ diameter) were used to collect undisturbed soil to measure soil bulk density. Geographical position and elevation of each plot were also recorded. Forty-eight soil samples per land use were collected making a total of 96 samples.

\section{Soil physical and chemical analysis}

The SOM was fractionated following procedures described by [25]. Air-dried sub samples were sieved and 20 g placed in $250 \mathrm{ml}$ plastic bottle. $70 \mathrm{ml}$ of sodium hexa-metaphosphate solution was added and the mixture shaken for $15 \mathrm{~h}$ on an end to end shaker. The contents were passed through a series of sieves $(2 \mathrm{~mm}, 250$ and $53 \mu)$ and the fractions collected dried at $50{ }^{\circ} \mathrm{C}$ for $48 \mathrm{~h}$ in an air oven. The 53-250 $\mu$ fraction was referred to as labile SOM. All the material that passed through the $53 \mu$ sieve was collected in a flask, swirled to mix thoroughly and a sample of $100 \mathrm{ml}$ taken and oven dried. This sample was referred to as the stable SOM. The oven-dried fractions were ground using mortar and pestle to a very fine material, sieved through a $0.149 \mathrm{~mm}$ sieve and analysed for SOC [40].

\section{ENpoc and carbon management index}

The enrichment ratio of the labile carbon, was calculated by dividing it by the total organic carbon of the same land use. Carbon management index is an assessment model that shows how a particular land use affects the soil quality relative to a reference land use soil.

The index is formulated as follows:

$$
C M I=C P I * L I * 100
$$

where CPI is the carbon pool index and LI is the lability index of the soil under a particular landuse [4].

$$
\mathrm{CPI}=\frac{\text { Total carbon in the treatment } \mathrm{g} \mathrm{kg}^{-1}}{\text { Total carbon in the reference } \mathrm{g} \mathrm{kg}^{-1}}
$$

$$
L I=\frac{\mathrm{L} \text { in the treatment }}{\mathrm{L} \text { in the reference }}
$$

where $\mathrm{L}$ is carbon lability of the soil

$$
\mathrm{L}=\frac{\text { Content of labile } \mathrm{C}}{\text { Content on non-labile C }}
$$

In this study, the native shrubland was used as reference land use. This is because it has been under rehabilitation for the last 4 years and it is enclosed from grazing and other disturbances.

\section{Statistical analyses}

Analysis of variance (ANOVA) and Duncan's multiple range test (DMRT) for comparison of means were performed using software SAS 9.1.3. The statistical significance was determined at $\mathrm{P}<0.05$. Effects of land use and soil depth on SOC fractions were analysed by a two-way ANOVA. A simple linear regression analysis was used to reveal the relationship between TOC and its fractions.

\section{Results and discussion \\ Total soil organic carbon}

Shrublands recorded the highest TOC with $22.26 \mathrm{~g} \mathrm{~kg}^{-1}$ the surface layer and $7.56 \mathrm{~g} \mathrm{~kg}^{-1}$ in the sub-surface layers.

The TOC (Fig. 2) in SH was the highest in the surface layer $\left(22.26 \mathrm{~g} \mathrm{~kg}^{-1}\right)$ which was significantly different $(\mathrm{P}<0.05)$ from the other land use types probably because it was fenced from grazing. BL had the lowest with $7.56 \mathrm{~g} \mathrm{~kg}^{-1}$ due to low surface cover. Total organic carbon was significantly different between all the LUTs at $0-15 \mathrm{~cm}$. In the sub-surface, BL and GR were not significantly different, and both were low compared to $\mathrm{SH}$ and AG. Shrubland recorded the highest TOC $\left(18.06 \mathrm{~g} \mathrm{~kg}^{-1}\right)$ which was significantly different from AG $\left(12.07 \mathrm{~g} \mathrm{~kg}^{-1}\right)$. TOC was higher in the $0-15 \mathrm{~cm}$ than in $15-30 \mathrm{~cm}$.

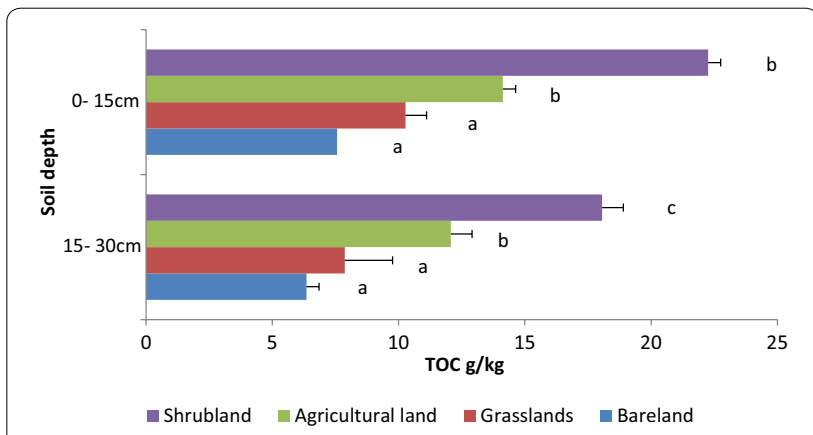

Fig. 2 Total organic carbon (TOC) under different land cover types. Means in the same colour with different letters indicate highly significant $(P<0.05)$ 


\section{Particulate organic matter}

The POC was significantly highest in $\mathrm{SH}$ and lowest in $\mathrm{BL}$ across all layers.

For POC, SH had the highest $\left(7.79 \mathrm{~g} \mathrm{~kg}^{-1}\right)$ which was significantly different from the other LUTs. AG had $\left(3.82 \mathrm{~g} \mathrm{~kg}^{-1}\right)$ while GR had $\left(2.46 \mathrm{~g} \mathrm{~kg}^{-1}\right)$ which was not significantly different from $\mathrm{BL}\left(1.51 \mathrm{~g} \mathrm{~kg}^{-1}\right)$ at the surface layer. At $15-30 \mathrm{~cm} \mathrm{SH}$ and AG were significantly different at 4.93 and $2.70 \mathrm{~g} \mathrm{~kg}^{-1}$ respectively. In GR and BL, the POC was lower compared to the other LUTs but were not significantly different from each other at 1.37 and $1.08 \mathrm{~g} \mathrm{~kg}^{-1}$ respectively.

\section{Mineral organic matter}

The MOC was higher than the POC in all the land use types.

Mineral organic carbon at the surface layer was higher than in $15-30 \mathrm{~cm}$ across all the LUTs. All the LUTs were significantly different in mean $\mathrm{MOC}$, with $\mathrm{SH}$ (10.04 $\left.\mathrm{g} \mathrm{kg}^{-1}\right)$ being the highest. AG $\left(8.17 \mathrm{~g} \mathrm{~kg}^{-1}\right)$, GR $\left(6.49 \mathrm{~g} \mathrm{~kg}^{-1}\right)$ and BL $\left(4.24 \mathrm{~g} \mathrm{~kg}^{-1}\right)$ recorded the lowest. At $15-30 \mathrm{~cm}, \mathrm{SH}$ was the highest $\left(8.15 \mathrm{~g} \mathrm{~kg}^{-1}\right)$ and was significantly different from the other LUTs. AG and GR were not significantly different from each other recording $\left(6.10 \mathrm{~g} \mathrm{~kg}^{-1}\right)$ and $\left(5.23 \mathrm{~g} \mathrm{~kg}^{-1}\right)$ respectively. BL was the lowest at $\left(3.60 \mathrm{~g} \mathrm{~kg}^{-1}\right)$.

\section{Carbon management index}

As shown in Table 2 the carbon $\mathrm{EN}_{\mathrm{POC}}$ is highest in $\mathrm{SH}$ and lowest in BL. The CMI was highest in AG and lowest in BL. In this study, SH was taken to be the reference land use type.

The $\mathrm{EN}_{\mathrm{POC}}$ was highest in $\mathrm{SH}$ (34.99\%) which was significantly different from the other LUTs. Barelands recorded the lowest $\mathrm{EN}_{\mathrm{POC}}$ of $19.97 \%$ followed by GR at $23.95 \%$ and $A G$ at $27.03 \%$ at $0-15 \mathrm{~cm}$ depth. In the subsurface, the $\mathrm{EN}_{\mathrm{POC}}$ were lower than the surface layer. Shrubland had the highest $\mathrm{EN}_{\mathrm{POC}}$ at $27.30 \%$ and which was significantly different from the others at 22.37, 17.40 and $17 \%$ for AG, GR and BL respectively. The CMI was highest in AG followed by GR then the least was BL (53, 41 and 31\%) respectively in the surface layer. At $15-30 \mathrm{~cm}$, the trend was similar with AG $(65.73 \%)>$ GR (28.93\%) > BL (22.77\%) with AG being significantly different from both GR and BL.

\section{Discussion}

Total organic carbon (TOC)

Shrublands had the highest TOC (Fig. 3). This is attributed to the recovery of above and below ground biomass found in the $\mathrm{SH}$ which is significantly higher than in AG and in GR. The litter deposition encourages turnover combined with a higher soil moisture content which is high due to the canopy provided by the trees found in this land use types. These results are similar to research done by [41] in the southern ASALs of Kenya, illustrating that $\mathrm{SH}$ increases TOC due to high carbon inputs. Although, other studies show that its root material has a greater influence on SOC than litter in the short term [42]. In addition, vegetation cover protects loss of SOC from the surface compared to other LUTs in the catchment. Other work on erosion studies have shown that protective cover over the surface reduces the impacts of wind and water erosion on surface horizons [7, 43-47]. Total organic carbon was lower in AG compared to SH. This may be due to the tillage practices that destroy soil aggregation

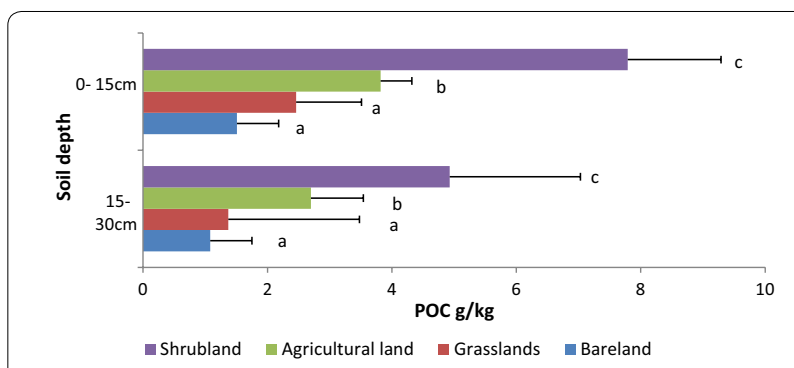

Fig. 3 Particulate organic matter (POC) under different land cover types. Means in the same colour with different letters indicate highly significant $(P<0.05)$

Table 2 Effects of land use types on carbon management index at different depths

\begin{tabular}{|c|c|c|c|c|c|c|c|c|}
\hline & \multicolumn{4}{|l|}{$0-15 \mathrm{~cm}$} & \multicolumn{4}{|c|}{$15-30 \mathrm{~cm}$} \\
\hline & $\mathrm{EN}_{\mathrm{POC}} \%$ & CPI & LI & CMI & $\mathrm{EN}_{\text {POC }} \%$ & CPI & LI & CMI \\
\hline $\mathrm{BL}$ & $19.97 a$ & $0.34 a$ & $0.80 a$ & $31.00 \mathrm{a}$ & $17.00 \mathrm{a}$ & $0.36 a$ & $0.59 a$ & $22.77 a$ \\
\hline GR & $23.95 a$ & $0.46 b$ & $0.81 a$ & 41.00ab & $17.40 \mathrm{a}$ & $0.46 a$ & $0.64 a b$ & $28.93 a$ \\
\hline$A G$ & $27.03 c$ & $0.64 c$ & $0.82 a$ & $53.00 \mathrm{~b}$ & $22.37 b$ & $0.68 a$ & $0.70 c$ & $65.73 b$ \\
\hline $\mathrm{SH}$ & $34.99 d$ & $1 d$ & $1 a$ & $100 c$ & $27.30 \mathrm{~b}$ & $1 c$ & $1 c$ & $100 c$ \\
\hline
\end{tabular}

Means with letters within are statistically different. $\mathrm{SH}$ is the reference land use type

$G R$ grasslands, $S H$ shrublands, $A G$ agricultural lands, $B L$ barelands, $E N_{P O C}$ enrichment ratio of POC to TOC, $C P I$ carbon pool index, $L I$ lability index, $C M I$ carbon management index 
and exposes organic matter to factors that encourage faster decomposition rate to carbon inputs [48], in Ethiopia showed that minimal disturbances on soil surfaces encourage microbial activity which increases TOC in the soil. Moreover, the harvesting of above ground biomass for animal feed instead of leaving it as stubble may also contribute to lower TOC $[49,50]$.

In the GR, the TOC was unexpectedly lower which may be attributed to the high grazing intensity within the catchment. Overgrazing affects carbon fluxes whereby the carbon inputs are less than the carbon outputs. Moreover, the cattle tracks in the GR increase the bulk density of the area therefore discouraging shoot emergence and encourage surface runoff. The area experiences high erosion rates $[33,36]$ which selectively carries away the SOC on the surface since it has a light density [51, 52]. A study done in Northern China on degraded grasslands showed that there was up to a $50 \%$ loss of SOC due to exposure of the surface resulting from land use change and overgrazing. This is contrary to a research done by [53] which showed that grasslands have higher capacity to store $\mathrm{SOC}$ than $\mathrm{SH}$, however in this study area there was controlled grazing. Differences were seen down the profile as TOC was higher in $0-15 \mathrm{~cm}$ than in $15-30 \mathrm{~cm}$. This can be attributed to higher rates of inputs of litter in the surface compared to roots in the sub-surface. Furthermore there is minimal rainfall in the area which discourages movement of carbon to the lower horizons [54].

The lower TOC in GR compared to SH can be attributed to the distribution of plant root systems which [55] suggest has more influence on soil organic matter than climate. The plant function types influence the vertical distribution of SOC within the profile [56] where grasses have a shallow root profile while shrubs have a deeper root profile. This can explain the higher TOC in SH and lower in GR in the sub-surface horizon. The presence of shrub roots in the lower horizons increases the TOC concentration with root exudates, microbial soil biomass and dehydrogenase activity $[57,58]$.

\section{Particulate organic carbon (POC)}

For the soil fractions studied, POC was the fraction most affected by land use within the catchment (Fig. 4). In SH, POC was the highest which can be attributed to higher litter deposits which have higher labile carbon $[59,60]$ that encourages microbial vitality and quantity. The $\mathrm{SH}$ are fenced, which regulate grazing and disturbance by both livestock and wildlife, moreover, the area has several physical soil management structures to reduce soil erosion and this may have contributed to higher POC. Similar results were found in in the central Himalayan region by [61] who showed that land use types that were undisturbed had higher POC due to accumulation of carbon that are protected by soil aggregates.

Agricultural land had lower POC than SH (Fig. 4). This is attributable to labile carbon that is highly dependent on management practices. Cultivation for example breaks down protective macroaggregates that expose the POC to higher rates of decomposition and mineralization. The concentration of POC in cultivated areas is mainly affected by tillage practices [62]. A study done by [49] to compare conventional tillage and no-till showed that POC decreased in the conventional tillage and increased in the no-till management. It was hypothesized that the breakdown of macro-aggregates and diminished binding agents leads to disintegration of the soil matrix which releases the labile carbon to a free state; this in turn increases its loss substantially from soil. In a similar study, Jacinthe et al. [63] concluded that farms with minimal cover on the soil in between seasons lost higher concentrations of labile carbon compared to those with cover.

Grasslands recorded low POC levels which were not significantly different from the BL (Fig. 4). These results are similar to those obtained by [11] in the desert steppe in Mongolia, which reflected low POC concentrations in medium and high intensity grazing management systems in China. This was attributed to low surface cover, low root biomass and the vulnerability of the soil to erosion. Herbivore influence on POC in soil is also reflected on selective harvesting of above ground biomass. Li et al. [64] reported that over extraction of green succulent herbage with little input leads to low POC, while other studies suggest that controlled grazing triggers enzymes that increase microbial activities leading to mineralization in the short term [65]. In the grasslands of northern Great Plains showed that different grazing regimes influenced plant species diversity, which showed correlation with high turnover carbon. The results indicate that high

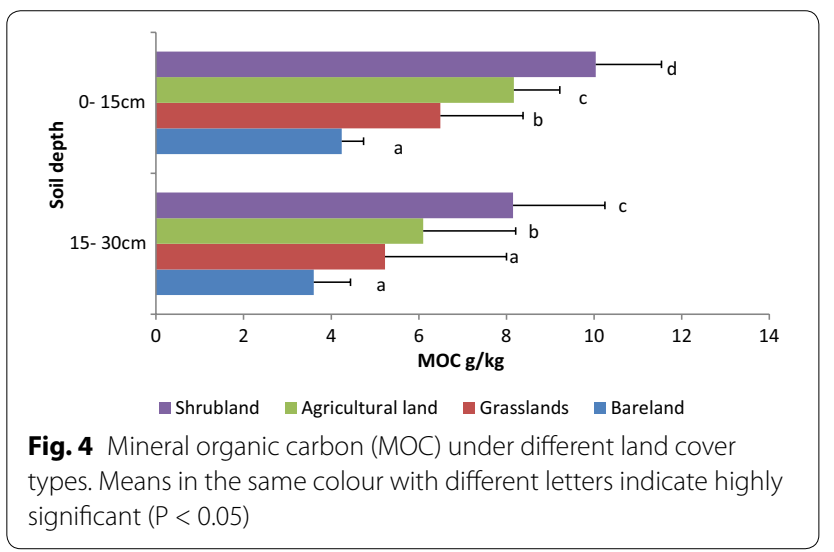


grazing intensity resulted in increased competition for easily available carbon, therefore reduced labile carbon. In contrast, other researchers concluded that grazing intensity led to decrease in plant function rather than low nutrient accumulation and that the latter was primarily due to erosion [66-68].

Due to exposure of the surface by overgrazing and patches of bareland, the erosion process has influenced the lateral carbon fluxes in each land use $[7,69,70]$. Similar studies by $[8,71]$ illustrate that POC being the lighter fraction is easily carried away in semi-arid areas with poor soil management structures. The POC waslow in all land use types. This may be because POC is generally lower compared to MOC in soil; as it is related to light sand size fractions that are easily carried away by water erosion [72]. Furthermore, POC does not form organocomplexes with minerals therefore making it susceptible to mineralization [73]. Comparable results are seen in woodlands of Tanzania where enrichment of POC to the total was lower than that of the, stable or the silt-clay organic fractions [74].

\section{Mineral organic carbon (MOC)}

Mineral organic carbon or stable organic carbon was not as sensitive to land uses as POC. These results are comparable to those of [75] in India and [76] in Northern China which showed that the recalcitrant material showed minimal decrease across different land use types most likely due to the inaccessibility of MOC because of the strong bonds created between the clay surfaces and the soil organic carbon. Other studies have shown that MOC is more sensitive to land use management for example [21] working in the Kenyan central Highlands showed that different potato cropping systems affect the stable fraction more than the labile one. While [77] observed in Northern Germany that MOC was more sensitive to land use change compared to TOC. This could be attributed to the fact that erosion sorts out particles mainly according to their sizes, in which in the areas have high levels of clay particles compared to the study area of this research. Therefore the finer silt and clay particles were highly enriched with MOC therefore mobilised larger quantities.

\section{Carbon management index (CMI)}

For $\mathrm{EN}_{\mathrm{POC}}, \mathrm{SH}$ registered the highest values (Table 2). This is because $\mathrm{SH}$ provide a less oxidative environment for POC breakdown, due to the presence of the thicket canopy, protective structure of the macroaggregates and lower erodability enabling POC build-up. These results are similar to those obtained by [4] that showed low disturbance in native grasslands increased the lability of carbon to TOC. Similarly, in Brazil, [78] undertook a study to evaluate no-till management system and compared it to a native pasture land with minimum disturbance. The results illustrated that higher $\mathrm{EN}_{\mathrm{POC}}$ was recorded in the enclosed pastures similar to those with no-till of up to 20 years. The lower levels of $\mathrm{EN}_{\mathrm{POC}}, \mathrm{CPI}$ and $\mathrm{LI}$ in GR indicate that this land use type is at a more advanced stage of degradation compared to AG which has been under cultivation for the last 7 years [36]. This translates to lower $\mathrm{C}$ inputs and higher turnover rates due to high temperature as well as SOC erosion. Similar results have been obtained by $[11,79]$.

The high CMI values in AG may be linked to the use of fertilizer on the farms. The use of nitrogen based fertilizer has been seen to increase biomass therefore increase soil organic matter in soil. These results are comparable to [14] who showed that in corn cropping systems, addition of fertilizer and stubble increases the lability of SOM by $12-46 \%$ therefore increasing CMI. In GR, overgrazing was seen to reduce the $C$ content which can be attributable to reduction of herbaceous fine root biomass [80] thereby reducing the CMI of grasslands.

There is no definite standard for CMI as it is based on the native land use of an area; however [4] suggested that higher CMI values indicate rehabilitation of carbon while lower CMI values show that the $C$ is being degraded. Moreover, according to [81] the land use with the higher CMI seems to provide better options for $\mathrm{C}$ rehabilitation.

\section{Conclusions}

This study shows that different land use types have an influence on soil organic carbon pools and consequently the CMI. The labile fraction represented by POC is low across all the land use types and at different soil depths. Shrublands had the highest POC value which may be attributed to higher litter input and low disturbance compared to the other LUTs. The levels of POC in AG are linked to the use of fertilizer and intercropping that is practised in the catchment. In grasslands the unexpectedly lower POC levels are linked to the high levels of over grazing leading to low herbaceous litter input. The MOC was higher than the POC due to the fact that it is not easily influenced by soil management systems. In order to assess the sensitivity of the POC to LUTs, the CMI showed that level of degradation in the GR was as severe as that of BL. Therefore efforts aimed at improving SOM within each land use types will improve the soil quality and otherwise reverse degradation within the catchment. The study recommends immediate action on the grazing management strategies to reduce above ground biomass harvesting to encourage build-up of SOC. Soil management strategies should be employed in the agricultural areas to increase the labile pool consequently improve the long term fertility of the soils. 


\section{Authors' contributions}

The corresponding author was the lead researcher, in data collection, analysis and writing of the paper. CG was lead in the design of the project, methodology and design. AK was lead in processing of the data and research paper writing. All authors read and approved the final manuscript.

\section{Author details}

${ }^{1}$ Department of Land Resource Management and Agricultural Technology, University of Nairobi, P.O Box 29053, Nairobi 00625, Kenya. ${ }^{2}$ Mainstreaming Sustainable land management in Agro-pastoral production, Kenya Project, United Nations Development Programme Kenya (UNDP-K), P.O. Box 30218, Nairobi 00100, Kenya.

\section{Acknowledgements}

The project was supported by Mainstreaming Sustainable Land Management in Agro-pastoral Production of Kenya Project financed by the Global Environmental Facilities (GEF), United Nations Development Program-Kenya (UNDP-K) and the Government of Kenya, through the Ministry of Agriculture Livestock and Fisheries (MoALF). Technical support by Department of Land resource management and Agricultural technology (Larmat) is greatly appreciated.

\section{Competing interests}

The authors declare that they have no competing interests.

\section{Available data and materials}

All the data required is in the manuscript.

\section{Consent for publication}

Not applicable.

\section{Ethics approval and consent to participate} Not applicable.

\section{Publisher's Note}

Springer Nature remains neutral with regard to jurisdictional claims in published maps and institutional affiliations.

Received: 26 May 2017 Accepted: 1 February 2018

Published online: 12 February 2018

\section{References}

1. Haynes RJ. Labile organic matter fractions as central components of the quality of agricultural soils: an overview. Adv Agron. 2005;85:221-68.

2. Lehmann J, Kleber M. The contentious nature of soil organic matter. Nature. 2015;528(7580):60-8.

3. Yang X, Ren W, Sun B, Zhang S. Effects of contrasting soil management regimes on total and labile soil organic carbon fractions in a loess soil in China. Geoderma. 2012:177:49-56.

4. Blair GJ, Lefroy RD, Lisle L. Soil carbon fractions based on their degree of oxidation, and the development of a carbon management index for agricultural systems. Crop Pasture Sci. 1995;46(7):1459-66.

5. Diekow J, Mielniczuk J, Knicker H, Bayer C, Dick DP, Kögel-Knabner I. Soil $\mathrm{C}$ and $\mathrm{N}$ stocks as affected by cropping systems and nitrogen fertilisation in a southern Brazil Acrisol managed under no-tillage for 17 years. Soil Tillage Res. 2005;81(1):87-95.

6. Six J, Feller C, Denef K, Ogle S, de Moraes Sa JC, Albrecht A. Soil organic matter, biota and aggregation in temperate and tropical soils-effects of no-tillage. Agronomie. 2002;22(7-8):755-75.

7. Berhe AA, Harden JW, Torn MS, Kleber M, Burton SD, Harte J. Persistence of soil organic matter in eroding versus depositional landform positions. J Geophys Res Biogeosci. 2012;117(G2):1-6. https://doi. org/10.1029/2011JG001790.

8. Wang R, Filley TR, Xu Z, Wang X, Li MH, Zhang Y, Jiang Y. Coupled response of soil carbon and nitrogen pools and enzyme activities to nitrogen and water addition in a semi-arid grassland of Inner Mongolia. Plant Soil. 2014;381(1-2):323-36.

9. Weil RR, Islam KR, Stine MA, Gruver JB, Samson-Liebig SE. Estimating labile carbon for soil quality assessment: a simplified method for laboratory and field use. Am J Altern Agric. 2003;18(1):3-17. https://doi.org/10.1079/ AJAA2003003.

10. Mirsky SB, Lanyon LE, Needelman BA. Evaluating soil management using particulate and chemically labile soil organic matter fractions. Soil Sci Soc Am J. 2008;72(1):180-5.

11. Cao J, Wang $X$, Sun $X$, Zhang $L$, Tian $Y$. Effects of grazing intensity on soil labile organic carbon fractions in a desert steppe area in Inner Mongolia. Springer Plus. 2013;2(1):S1.

12. Alvarez R, Alvarez CR. Soil organic matter pools and their associations with carbon mineralization kinetics. Soil Sci Soc Am J. 2000;64:184-9.

13. Murage EW, Karanja NK, Smithson PC, Woomer PL. Differences in soil properties between productive and non-productive fields identified by small hold farmers in the Central Highlands of Kenya. Agric Ecosyst Environ. 2001;79:1-8

14. Vieira FCB, Bayer C, Zanatta JA, Dieckow J, Mielniczuk J, He ZL. Carbon management index based on physical fractionation of soil organic matter in an Acrisol under long-term no-till cropping systems. Soil Tillage Res. 2007:96(1):195-204.

15. Hamilton EW, Frank DA. Can plants stimulate soil microbes and their own nutrient supply? Evidence from a grazing tolerant grass. Ecology. 2001;82(9):2397-402

16. Melillo JM, Steudler PA, Aber JD, Newkirk K, Lux H, Bowles FP, Catricala C, Magill A, Ahrens T, Morrisseau S. Soil warming and carbon-cycle feedbacks to the climate system. Science. 2002;298(5601):2173-6.

17. Knorr W, Prentice IC, House II, Holland EA. Long-term sensitivity of soil carbon turnover to warming. Nature. 2005:433(7023):298-301.

18. Rui Y, Wang S, Xu Z, Wang Y, Chen C, Zhou X, Luo C. Warming and grazing affect soil labile carbon and nitrogen pools differently in an alpine meadow of the Qinghai-Tibet Plateau in China. J Soils Sediments. 2011;11(6):903-14.

19. Bayer C, Dick DP, Ribeiro GM, Scheuermann KK. Carbon stocks in organic matter fractions as affected by land use and soil management, with emphasis on no-tillage effect. Ciência Rural. 2002·32(3):401-6.

20. Klotzbücher T, Kaiser K, Guggenberger G, Gatzek C, Kalbitz K. A new conceptual model for the fate of lignin in decomposing plant litter. Ecology. 2011;92(5):1052-62.

21. Nyawade SO. Effect of potato (Solanum tuberosum L.) cropping systems on soil and nutrient losses through runoff in a humic Nitisol (Doctoral dissertation, University of Nairobi). 2015.

22. Allen $\mathrm{DE}$, Pringle $\mathrm{MJ}$, Page $\mathrm{KL}$, Dalal $\mathrm{RC}$. A review of sampling designs for the measurement of soil organic carbon in Australian grazing lands. Rangel J. 2010;32(2):227-46.

23. Shang $\mathrm{C}$, Tiessen $\mathrm{H}$. Organic matter lability in a tropical oxisol: evidence from shifting cultivation, chemical oxidation, particle size, density, and magnetic fractionations. Soil Sci. 1997;162(11):795-807.

24. Baldock JA, Nelson PN. Soil organic matter. Boca Raton: CRC Press; 2000

25. Camberdella CA, Elliott ET. Particulate soil organic-matter changes across a grassland cultivation sequence. Soil Sci Soc Am J. 1992;56(3):777-83.

26. Leifeld J, Kögel-Knabner I. Soil organic matter fractions as early indicators for carbon stock changes under different land-use? Geoderma. 2005:124(1):143-55.

27. Blair N, Faulkner RD, Till AR, Poulton PR. Long-term management impacts on soil C, N and physical fertility: part I: Broadbalk experiment. Soil Tillage Res. 2006;91(1):30-8.

28. Serneels $S$, Lambin EF. Proximate causes of land-use change in Narok District, Kenya: a spatial statistical model. Agric Ecosyst Environ. 2001:85(1):65-81.

29. Jaeztold R, Helmut Schmidt H, Berthold Hornetz B, Shisanya C. Farm. 2010.

30. Ruto AC. Optimizing moisture and nutrient variability under different cropping patterns in terraced farms for improved crop performance in Narok County, Kenya (Doctoral dissertation, University of Nairobi). 2015.

31. National Environment Management Authority. State of the environment and outlook. A publication of the National Environment Management Authority (NEMA), Kenya. 2010.

32. Ojwang GO, Agatsiva J, Situma C. Analysis of climate change and variability risks in the smallholder sector case studies of the Laikipia and Narok Districts representing major agro-ecological zones in Kenya. Rome: Electric Publishing Policy and Support Branch Community Division, FAO; 2010.

33. Khalif $Z$, et al. Sustainable land management in drylands of Kenya: improving land productivity through participatory research and technology transfer. Kenya: United Nations Development Programme; 2015. 
34. Odini L, Ombasa B, Mutungi K. Knowledge based sustainable land use of Cornell University. 2015

35. Reed MS, Dougill AJ, Baker TR. Participatory indicator development: what can ecologists and local communities learn from each other. Ecol Appl. 2008;18(5):1253-69.

36. Maina J. Mainstreaming sustainable land management in agropastoral production systems of Kenya: Narok project target area baseline survey report. 2013.

37. Skidmore AK, Ferwerda JG. Resource distribution and dynamics: mapping herbivoreresources. In: Prins HHT, Van Langevelde F (editor) Resource Ecology. Wageningen UR Frontis Series, vol 23. Dordrecht: Springer; 2008. pp. 57-77.

38. SombroekWG, Braun HMH, Van der Pouw BJA. Exploratory soil map and agroclimatic zone map of Kenya, 1980. Scale 1: 1,000,000. Kenya Soil Survey. 1982.

39. Gachene CK. Characterization and assessment of erodibility indexes of Suswa andosols. (Unpublished report). 2014.

40. Walkley A, Black IA. An examination of the Degtjareff method for determining soil organic matter, and a proposed modification of the chromic acid titration method. Soil Sci. 1934;37(1):29-38.

41. Mganga KZ, Musimba NK, Nyariki DM, Nyangito MM, Ekaya WN, Muiru WM, Mwang'ombe AW. Different land use types in the semi-arid rangelands of Kenya influence soil properties. 2011.

42. Rumpel C, Kögel-Knabner I. Deep soil organic matter — a key but poorly understood component of terrestrial C cycle. Plant Soil. 2011;338(1-2):143-58.

43. Lal R. Soil carbon sequestration impacts on global climate change and food security. Science. 2004;304(5677):1623-7.

44. Lal R. Soil carbon sequestration in natural and managed tropical forest ecosystems. J Sustain For. 2005;21:1-30.

45. Jacinthe PA, Lal R, Kimble JM. Carbon budget and seasonal carbon dioxide emission from a central Ohio Luvisol as influenced by wheat residue amendment. Soil Tillage Res. 2002;67(2):147-57.

46. Devagiri GM, Money S, Singh S, Dadhawal VK, Patil P, Khaple A, Hubballi S. Assessment of above ground biomass and carbon pool in different vegetation types of south western part of Karnataka. India using spectral modelling. Trop Ecol. 2013;54(2):149-65.

47. Yu P, Li Q, Jia H, Zheng W, Wang M, Zhou D. Carbon stocks and storage potential as affected by vegetation in the Songnen grassland of northeast China. Quat Int. 2013;306:114-20.

48. Gelaw AM, Singh BR, Lal R. Organic carbon and nitrogen associated with soil aggregates and particle sizes under different land uses in Tigray, Northern Ethiopia. Land Degrad Dev. 2015;26(7):690-700.

49. Six J, Elliott ET, Paustian K, Doran JW. Aggregation and soil organic matter accumulation in cultivated and native grassland soils. Soil Sci Soc Am J. 1998:62(5):1367-77.

50. Wang Q, Zhang L, Li L, Bai Y, Cao J, Han X. Changes in carbon and nitrogen of Chernozem soil along a cultivation chronosequence in a semi-arid grassland. Eur J Soil Sci. 2009;60(6):916-23.

51. Lal R. Carbon sequestration. Philos Trans R Soc B Biol Sci. 2008:363(1492):815-30

52. Were K, Bui DT, Dick ØB, Singh BR. A comparative assessment of support vector regression, artificial neural networks, and random forests for predicting and mapping soil organic carbon stocks across an Afromontane landscape. Ecol Ind. 2015:52:394-403.

53. Franzluebbers AJ, Stuedemann JA, Schomberg HH, Wilkinson SR. Soil organic $C$ and $\mathrm{N}$ pools under long-term pasture management in the Southern Piedmont USA. Soil Biol Biochem. 2000;32(4):469-78.

54. O'Brien BJ, Stout JD. Movement and turnover of soil organic matter as indicated by carbon isotope measurements. Soil Biol Biochem. 1978;10(4):309-17.

55. Jobbágy EG, Jackson RB. The vertical distribution of soil organic carbon and its relation to climate and vegetation. Ecol Appl. 2000;10(2):423-36.

56. Jackson RB, Canadell J, Ehleringer JR, Mooney HA, Sala OE, Schulze ED. A global analysis of root distributions for terrestrial biomes. Oecologia. 1996;108(3):389-411.

57. Cao H, Zhao X, Wang S, Zhao L, Duan J, Zhang Z, Ge S, Zhu X. Grazing intensifies degradation of a Tibetan Plateau alpine meadow through plant-pest interaction. Ecol Evol. 2015;5(12):2478-86.

58. Lalitha M, Kumar P. Soil carbon fractions influenced by temperature sensitivity and land use management. Agrofor Syst. 2016;90(6):961-4.

59. Laik R, Kumar K, Das DK, Chaturvedi OP. Labile soil organic matter pools in a calciorthent after 18 years of afforestation by different plantations. Appl Soil Ecol. 2009:42(2):71-8
60. Barreto PA, Gama-Rodrigues EF, Gama-Rodrigues AC, Fontes AG, Polidoro JC, Moço MK, Machado RC, Baligar VC. Distribution of oxidizable organic C fractions in soils under cacao agroforestry systems in Southern Bahia, Brazil. Agrofor Syst. 2011;81(3):213-20.

61. Kalambukattu JG, Singh R, Patra AK, Arunkumar K. Soil carbon pools and carbon management index under different land use systems in the Central Himalayan region. Acta Agriculturae Scand Sect B Soil Plant Sci. 2013;63(3):200-5

62. Bayer C, Martin-Neto L, Mielniczuk J, Pavinato A, Dieckow J. Carbon sequestration in two Brazilian Cerrado soils under no-till. Soil Tillage Res. 2006;86(2):237-45.

63. Jacinthe PA, Lal R, Owens LB, Hothem DL. Transport of labile carbon in runoff as affected by land use and rainfall characteristics. Soil Tillage Res. 2004;77(2):111-23.

64. Li ZW, Nie XD, Chen XL, Lu YM, Jiang WG, Zeng GM. The effects of land use and landscape position on labile organic carbon and carbon management index in red soil hilly region, southern China. J Mt Sci. 2015:12(3):626-36.

65. Derner JD, Briske DD, Boutton TW. Does grazing mediate soil carbon and nitrogen accumulation beneath $C 4$, perennial grasses along an environmental gradient? Plant Soil. 1997;191(2):147-56.

66. Belsky AJ, Amundson RG, Duxbury JM, Riha SJ, Ali AR, Mwonga SM. The effects of trees on their physical, chemical and biological environments in a semi-arid savanna in Kenya. J Appl Ecol. 1989;26(3):1005-24.

67. Murphy JS, Briske DD. Regulation of tillering by apical dominance: chronology, interpretivevalue, and current perspectives. Rangeland Ecology \& Management/Journal of Range ManagementArchives. 1992;45(5):419-30.

68. Burke IC, Lauenroth WK, Parton WJ. Regional and temporal variation in net primary production and nitrogen mineralization in grasslands. Ecology. 1997;78(5):1330-40.

69. Berhe AA, Harte J, Harden JW, Torn MS. The significance of the erosioninduced terrestrial carbon sink. Bioscience. 2007;57(4):337-46.

70. Hoffmann T, Mudd SM, van Oost K, Verstraeten G, Erkens G, Lang A, Middelkoop H, Boyle J, Kaplan J, Willenbring J, Aalto R. Supplementary material to manuscript: humans and the missing C-sink: erosion and burial of soil.

71. Li Y, Jiao J, Wang Z, Cao B, Wei Y, Hu S. Effects of revegetation on soil organic carbon storage and erosion-induced carbon loss under extreme rainstorms in the hill and gully region of the Loess Plateau. Int J Environ Res Public Health. 2016;13(5):456.

72. Lal R. Forest soils and carbon sequestration. For Ecol Manag. 2005;220(1):242-58.

73. Christensen BT. Effects of animal manure and mineral fertilizer on the total carbon and nitrogen contents of soil size fractions. Biol Fertil Soils. 1988:5(4):304-7.

74. Solomon D, Lehmann J, Zech W. Land use effects on soil organic matter properties of chromic luvisols in semi-arid northern Tanzania: carbon, nitrogen, lignin and carbohydrates. Agric Ecosyst Environ. 2000;78(3):203-13.

75. Datta A, Basak N, Chaudhari SK, Sharma DK. Soil properties and organic carbon distribution under different land uses in reclaimed sodic soils of North-West India. Geoderma Reg. 2015:4:134-46.

76. Yu P, Han K, Li Q, Zhou D. Soil organic carbon fractions are affected by different land uses in an agro-pastoral transitional zone in North-eastern China. Ecol Ind. 2017;73:331-7.

77. Spohn M, Giani L. Impacts of land use change on soil aggregation and aggregate stabilizing compounds as dependent on time. Soil Biol Biochem. 2011;43(5):1081-8

78. Guareschi RF, Pereira MG, Perin A. Oxidizable carbon fractions in Red Latosol under different management systems. Revisit Ciência Agronômica. 2013:44(2):242-50

79. Rangel OJPI, Silva CA, Guimarães PTG, Guilherme LRG. Frações oxidáveis do carbono orgânico de Latossolo cultivado com cafeeiro em diferentes espaçamentos de plantio. Ciência e agrotecnologia. 2008.

80. Liu JB, Zhang YQ, Wu B, Qin SG, Lai ZR. Changes in soil organic carbon and its density fractions after shrub-planting for desertification control. Pol J Ecol. 2014:62(2):205-16.

81. Benbi DK, Brar K, Toor AS, Singh P. Total and labile pools of soil organic carbon in cultivated and undisturbed soils in northern India. Geoderma. 2015:237:149-58. 